\title{
Chronic Pain Induces Anxiety with Concomitant Changes in Opioidergic Function in the Amygdala
}

\author{
Minoru Narita*,', Chihiro Kaneko', Kan Miyoshi', Yasuyuki Nagumo', Naoko Kuzumaki', \\ Mayumi Nakajima', Kana Nanjo', Kiyomi Matsuzawa ${ }^{1,2}$, Mitsuaki Yamazaki ${ }^{2}$ and Tsutomu Suzuki*,' \\ 'Department of Toxicology, Hoshi University School of Pharmacy and Pharmaceutical Sciences, Shinagawa-ku, Tokyo, Japan; ${ }^{2}$ Department of \\ Anesthesiology, Toyama Medical and Pharmaceutical University, Toyama, Japan
}

\begin{abstract}
Clinically, it has been reported that chronic pain induces depression, anxiety, and reduced quality of life. The endogenous opioid system has been implicated in nociception, anxiety, and stress. The present study was undertaken to investigate whether chronic pain could induce anxiogenic effects and changes in the opioidergic function in the amygdala in mice. We found that either injection of complete Freund's adjuvant (CFA) or neuropathic pain induced by sciatic nerve ligation produced a significant anxiogenic effect at 4 weeks after the injection or surgery. Under these conditions, the selective $\mu$-opioid receptor agonist $\left[\mathrm{D}-\mathrm{Ala}^{2}, \mathrm{~N}-\mathrm{MePhe}{ }^{4}, \mathrm{Gly}{ }^{5}\right.$-ol]-enkephalin (DAMGO)and the selective $\delta$-opioid receptor agonist $(+)-4-[(\alpha \mathrm{R})-\alpha-((2 S, 5 \mathrm{R})-4$-allyl-2,5-dimethyl-I-piperazinyl)-3-methoxybenzyl]-N,N-diethylbenzamide (SNC80)-stimulated $\left[{ }^{35} \mathrm{~S}\right] \mathrm{GTP} \gamma \mathrm{S}$ binding in membranes of the amygdala was significantly suppressed by CFA injection or nerve ligation. CFA injection was associated with a significant increase in the $\kappa$-opioid receptor agonist 2-(3,4-dichlorophenyl)- $N$-methyl$\mathrm{N}$-[(IS)-I-phenyl-2-(I-pyrrolidinyl)ethy|]acetamide hydrochloride (ICII99,44I)-stimulated $\left.{ }^{35} \mathrm{~S}\right] \mathrm{GTP} \gamma \mathrm{S}$ binding in membranes of the amygdala. The intracerebroventricular administration and microinjection of a selective $\mu$-opioid receptor antagonist, a selective $\delta$-opioid receptor antagonist, and the endogenous $\kappa$-opioid receptor ligand dynorphin A caused a significant anxiogenic effect in mice. We also found that thermal hyperalgesia induced by sciatic nerve ligation was reversed at 8 weeks after surgery. In the light-dark test, the time spent in the lit compartment was not changed at 8 weeks after surgery. Collectively, the present data constitute the first evidence that chronic pain has an anxiogenic effect in mice. This phenomenon may be associated with changes in opioidergic function in the amygdala. Neuropsychopharmacology (2006) 31, 739-750. doi: I0.1038/sj.npp. I 300858; published online 10 August 2005
\end{abstract}

Keywords: pain; anxiety; opioid; amygdala

\section{INTRODUCTION}

Clinically, it has been reported that chronic pain induces depression, anxiety, and reduced quality of life (Gallagher et al, 1995; Von Korff and Simon, 1996). There have been many reports on the relation between pain and emotion. Many of these reports deal with the effects of enhanced emotional regulation on pain, and the relation between emotional distress and the seeking of treatment by individuals who are experiencing pain. It has been estimated that over $50 \%$ of patients who suffer from chronic pain also express clinically diagnosable symptoms of depression (Dworkin and Gitlin, 1991). Based on reports of the comorbidity between chronic pain and depressive illness in human patients, it is possible that these disease states are linked.

\footnotetext{
* Correspondence: Dr M Narita and Dr T Suzuki, Department of Toxicology, Hoshi University School of Pharmacy and Pharmaceutical Sciences, 2-4-4I Ebara, Shinagawa-ku, Tokyo I42-850 I, Japan, Tel/Fax: +8I 35498 5628, E-mails: narita@hoshi.ac.jp, suzuki@hoshi.ac.jp Received 7 March 2005; revised 21 June 2005; accepted 23 June 2005 Online publication: 5 July 2005 at http://www.acnp.org/citations/ Npp070505050 159/default.pdf
}

Opioid receptors belong to the large superfamily of Gprotein-coupled receptors. Three opioid receptor types, $\mu$-, $\delta$-, and $\kappa$-opioid receptors, have been successfully cloned (Evans et al, 1992; Kieffer et al, 1992; Chen et al, 1993; Fukuda et al, 1993; Meng et al, 1993; Wang et al, 1993; Yasuda et al, 1993). Opioid analgesics and endogenous opioid peptides have a wide range of physiological and behavioral effects on pain perception, motivation, locomotion, regulation of intestinal motility, immunomodulation, thermo-regulation, neuroendocrine secretion, and rewarding effects (Pasternak, 1988; Mansour et al, 1988; Cahill et al, 2001). It is well known that endogenous opioid peptides are released in the central nervous system in response to stressful stimuli, and activation of $\mu$-opioid receptor plays an important role in stressful conditions (Kiritsy-Roy et al, 1986; degli Uberti et al, 1995). $\delta$-Opioid receptors have also been associated with anxiety and depression, since $\delta$-agonists reduced the immobility of rats in a forced swimming test (Broom et al, 2002). Furthermore, $\kappa$ agonists produce a dysphoria similar to that noted in depression and chronic stress (Pfeiffer et al, 1986).

The present study was then undertaken to investigate whether chronic pain could induce anxiogenic effects and 
alter opioidergic functions in the amygdala, which is a key structure in the regulation of anxiety and the expression of emotional responses to stress in mice.

\section{EXPERIMENTAL PROCEDURES}

The present study was conducted in accordance with the Guiding Principles for the Care and Use of Laboratory Animals, Hoshi University, as adopted by the Committee on Animal Research of Hoshi University, which is accredited by Ministry of Education, Culture, Sports, Science and Technology of Japan. All efforts were made to minimize the number of animals used and their suffering.

\section{Animals}

Male C57BL/6J mice (CLEA Japan, Inc., Tokyo, Japan), weighing $18-23 \mathrm{~g}$, and SD rats, weighting $250-280 \mathrm{~g}$, were used in the present study. Animals were kept in a room with an ambient temperature of $23 \pm 1^{\circ} \mathrm{C}$ and a 12-h light-dark cycle (lights on 0800 to 2000). Food and water were available ad libitum. All animals were housed individually. All behavioral studies were performed during the light period.

\section{Nerve Injury Pain Model}

The mice were anesthetized with sodium pentobarbital $(70 \mathrm{mg} / \mathrm{kg}$, i.p.). We produced a neuropathic pain model by tying a tight ligature with $8-0$ silk suture around approximately $1 / 3-1 / 2$ the diameter of the sciatic nerve located in the right hind paw side (ipsilateral side) as described previously (Narita et al, 2000). In sham-operated mice, the nerve was exposed without ligation.

\section{Chronic Inflammatory Pain Model}

A persistent inflammatory pain model was produced by unilateral intraplantar injection of complete Freund's adjuvant (CFA; Mycobacterium tuberculosis; Sigma, St Louis, MO, USA) in a volume of $50 \mu$ linto the plantar surface of the right hind paw (ipsilateral side) of mice under anesthesia with sodium pentobarbital $(70 \mathrm{mg} / \mathrm{kg}$, i.p.) (Ohsawa et al, 2000). Control mice were given saline into the plantar surface of the right hind paw.

\section{Measurement of Thermal and Tactile Thresholds}

To assess the sensitivity to thermal stimulation, the right plantar surface of mice was tested individually using a wellfocused, radiant heat light source (model 33 Analgesia Meter; IITC/Life Science Instruments, Woodland Hills, CA, USA). The intensity of the thermal stimulus was adjusted to achieve an average baseline paw-withdrawal latency of approximately $8-10 \mathrm{~s}$ in naive mice. The paw-withdrawal latency was determined as the average of three measurements per paw. Only quick hind paw movements (with or without licking of hind paws) away from the stimulus were considered to be a withdrawal response. Paw movements associated with locomotion or weight shifting were not counted as a response. The paws were measured alternating between left and right with an interval of more than $3 \mathrm{~min}$ between measurements. Before the behavioral responses to the thermal stimulus were tested, mice were habituated for at least $30 \mathrm{~min}$ in a clear acrylic cylinder $(15 \mathrm{~cm}$ high and $8 \mathrm{~cm}$ in diameter). Under these conditions, the latency of paw withdrawal in response to the thermal stimulus was tested. The data represent the average value for the pawwithdrawal latency of the right hind paw. To ascertain the acute effect of a selective benzodiazepine receptor agonist etizolam $(1 \mathrm{mg} / \mathrm{kg}$, s.c.) on the increased sensitivity to the thermal stimulation, each paw was measured just before and $30 \mathrm{~min}$ after etizolam $(1 \mathrm{mg} / \mathrm{kg}$, s.c.) injection at 7 days after nerve ligation. In the chronic experiment, mice were treated repeatedly with etizolam once a day for 3 weeks (from day 7 to day 28) after nerve ligation and the paw withdrawal latency was measured one day after last injection.

To quantify the sensitivity to a tactile stimulus, paw withdrawal in response to a tactile stimulus was measured using a bending force $(0.02 \mathrm{~g})$ applied by von Frey filaments (North Coast Medical, Inc., Morgan Hill, CA, USA) (Yajima et al, 2005). A von Frey filament was applied to the plantar surface of each hind paw for $3 \mathrm{~s}$, and this was repeated three times with an inter-trial interval of at least $5 \mathrm{~s}$. Each of the hind paws was tested individually. Paw withdrawal in response to a tactile stimulus was evaluated by the scoring as follows: 0 , no response; 1 , a slow and/or slight response to the stimulus; 2, a quick withdrawal response away from the stimulus without flinching or licking; 3, an intense withdrawal response away from the stimulus with brisk flinching and/or licking. The paw withdrawal in response to each filament was determined as the average of two scores per paw. Paw movements associated with locomotion or weight shifting were not counted as a response. The paws were measured alternating between left and right with an interval of more than $3 \mathrm{~min}$ between the measurements. Before the behavioral responses to tactile stimuli were tested, mice were habituated for at least $30 \mathrm{~min}$ on an elevated nylon mesh floor. Under these conditions, paw withdrawal in response to a tactile stimulus was tested.

\section{Light-Dark Test}

To investigate changes in anxiogenic-like effects, mice tested using the light-dark paradigm (Bilkei-Gorzo et al, 1998; Schramm et al, 2001). We used a box consisting of a small (mouse: $18 \times 13 \times 18 \mathrm{~cm}^{3}$; rat: $40 \times 25 \times 40 \mathrm{~cm}^{3}$ ) dimly lit compartment with black walls and a black floor, connected by a tunnel (mouse: $5 \mathrm{~cm}$ long; rat: $15 \mathrm{~cm}$ long) to a large (mouse: $18 \times 18 \times 18 \mathrm{~cm}^{3}$; rat: $40 \times 40 \times 40 \mathrm{~cm}^{3}$ ) intensely lit (500 lux) compartment with a white walls and a white floor. Each animal was placed in the dark compartment at the beginning of the observation session. Compartment entry and exit were defined as all four paws into and out of an arm, respectively. The time spent in the lit compartment was recorded for $10 \mathrm{~min}$.

\section{Elevated Plus-Maze Test}

We used the elevated plus-maze test as another measurement of anxiety. The elevated plus-maze test has been used extensively to identify novel anxiolytic agents and to investigate the physiological and neurochemical basis of anxiety (Dawson and Tricklebank, 1995). The elevated 
plus-maze consisted of two opposing open and two closed arms $\left(30 \times 6 \mathrm{~cm}^{2}\right.$ each $)$ joined by a common central platform $\left(9 \times 9 \mathrm{~cm}^{2}\right)$. The maze was elevated $40 \mathrm{~cm}$ above the floor. The closed arms were enclosed by $15 \mathrm{~cm}$ high walls, and the open arms were surrounded by $0.3-\mathrm{cm}$ ledges. Illumination of the open and closed arms and the central platform was approximately equal (100 lux). Arm entry and exit were defined as all four paws into and out of an arm, respectively. The results were calculated as mean ratios of the time spent in the open arms to the total time spent in both the open and closed arms. Entries to the open and closed arms were also scored. In order to ascertain the anxiolytic effect of etizolam, a single injection of etizolam $(1 \mathrm{mg} / \mathrm{kg}$, s.c.) was performed $30 \mathrm{~min}$ before the light-dark or the elevated-plus maze procedures. In the chronic experiment, mice were used for this procedure following repeated treatment with etizolam once a day for 3 weeks day 7 to day 28 after nerve ligation.

\section{Guanosine-5' $-o-\left(3-\left[{ }^{35} S\right]\right.$ thio $)$ Triphosphate $\left(\left[{ }^{35} S\right]\right.$ GTP $\left.\gamma S\right)$ Binding Assay}

The saline- or CFA-injected mice and sham-operated or sciatic nerve-ligated mice were decapitated at 4 weeks after injection or surgery. For membrane preparation, the brain was quickly removed and dissected including the basolateral amygdala, central nucleus, and medial nucleus of the amygdala (about $2 \times 2 \times 2 \mathrm{~mm}^{3}$ cubic weighting $35 \mathrm{mg}$ per mouse) according to the brain atlas of Paxinos $G$ and Franklin KBJ (The Mouse Brain, 2nd edn. Academic Press: CA, USA). The tissue was homogenized using a PotterElevehjem tissue grinder with a Teflon pestle in $20 \mathrm{vol}(\mathrm{w} / \mathrm{v})$ of ice-cold Tris- $\mathrm{Mg}^{2+}$ buffer containing $50 \mathrm{mM}$ Tris- $\mathrm{HCl}$, $\mathrm{pH} 7.4,5 \mathrm{mM} \mathrm{MgCl}_{2}$, and $1 \mathrm{mM}$ EGTA for the $\left[{ }^{35} \mathrm{~S}\right] \mathrm{GTP} \gamma \mathrm{S}$ binding assay. The homogenate was centrifuged at $4{ }^{\circ} \mathrm{C}$ for $10 \mathrm{~min}$ at $48000 \mathrm{~g}$. The pellet was resuspended in ice-cold Tris buffer or $\left[{ }^{35} \mathrm{~S}\right] \mathrm{GTP} \gamma \mathrm{S}$ binding assay buffer containing $50 \mathrm{mM}$ Tris- $\mathrm{HCl}, \mathrm{pH} 7.4,5 \mathrm{mM} \mathrm{MgCl}_{2}$, and $1 \mathrm{mM} \mathrm{EGTA}$ and $100 \mathrm{mM} \mathrm{NaCl}$ and centrifuged at $4^{\circ} \mathrm{C}$ for $10 \mathrm{~min}$ at $48000 \mathrm{~g}$. The resultant pellet was resuspended on ice-cold $\left[{ }^{35} \mathrm{~S}\right] \mathrm{GTP} \gamma \mathrm{S}$ binding assay buffer and stored at $-70^{\circ} \mathrm{C}$ until use.

The membrane homogenate $(3-8 \mu \mathrm{g}$ protein per assay) was incubated at $25^{\circ} \mathrm{C}$ for $2 \mathrm{~h}$ in $1 \mathrm{ml}$ of assay buffer with various concentrations of agonist, $30 \mu \mathrm{M}$ GDP, and $50 \mathrm{pM}$ $\left[{ }^{35} \mathrm{~S}\right] \mathrm{GTP} \gamma \mathrm{S}$ (specific activity, $1000 \mathrm{Ci} / \mathrm{mmol}$; Amersham Biosciences). The reaction was terminated by filtration using a Brandle cell harvester and Whatman GF/B glass filters presoaked in $50 \mathrm{mM}$ Tris- $\mathrm{HCl}, \mathrm{pH} 7.4$, and $5 \mathrm{mM}$ $\mathrm{MgCl}_{2}$ at $4{ }^{\circ} \mathrm{C}$ for $2 \mathrm{~h}$. Filters were then washed three times with $5 \mathrm{mM}$ ice-cold Tris- $\mathrm{HCl}$ buffer, $\mathrm{pH} 7.4$, transferred to scintillation-counting vials containing $0.5 \mathrm{ml}$ of Soluene-350 and $4 \mathrm{ml}$ of Hionic Fluor, and equilibrated for $12 \mathrm{~h}$, and the radioactivity in the samples was determined with a liquid scintillation analyzer. Nonspecific binding was measured in the presence of $10 \mu \mathrm{M}$ unlabeled GTP $\gamma$ S. Comparable results were obtained from at least three independent sets and in each set experiments were performed in triplicate.

\section{Intracerebroventricular Injection}

Intracerebroventricular administration was performed as described previously (Haley and McCormick, 1957). A few days before intracerebroventricular injection, the mice were lightly anesthetized with diethyl ether and a $2 \mathrm{~mm}$ double-needle tip: $27 \mathrm{G} \times 2 \mathrm{~mm}$ and base: $22 \mathrm{G} \times 10 \mathrm{~mm}$ (Natsume Seisakusho Co. Ltd, Tokyo, Japan) attached to a 25- $\mu$ l Hamilton microsyringe was inserted into the unilateral injection site; a hole was made in the skull for the injection. The solution was injected in a volume of $4 \mu \mathrm{l}$ per mouse.

\section{Surgery and Microinjection}

After 3 days of habituation to the main animal colony, all rats were anesthetized with sodium pentobarbital (50 mg/kg, i.p.). The anesthetized animals were placed in a stereotaxic apparatus. The skull was exposed and a small hole was made using a dental drill. A guide cannula (AG-9, Eicom Co., Kyoto, Japan) was implanted into the basolateral amygdala (from bregma: posterior $-2.8 \mathrm{~mm}$, lateral $+5.0 \mathrm{~mm}$, ventral $-7.9 \mathrm{~mm}$ ) according to the atlas of Paxinos and Watson (1998). The guide cannula was fixed to the skull with cranioplastic cement. At 7 days after surgery, the animals were injected with a selective $\mu$-opioid receptor antagonist CTOP, a $\delta$-opioid receptor antagonist NTI or dynorphin A into the basolateral amygdala $10 \mathrm{~min}$ before testing. In the microinjection study, we used the injection cannula (AMI-9.5, Eicom Co.) extended beyond the guide cannula by $0.5 \mathrm{~mm}$. A stainless steel injection cannula was inserted into that guide cannula for each animal. The injection cannula was connected through polyethylene tubing to a $10 \mu \mathrm{l}$ Hamilton syringe that was preloaded with CTOP, NTI, or dynorphin A $(0.1,1$, or $10 \mathrm{pmol} / 0.3 \mu \mathrm{l})$ or vehicle. The receptor antagonist or vehicle was delivered by motorized syringe pump in a volume of $0.3 \mu \mathrm{l}$ over $60 \mathrm{~s}$.

\section{Drugs}

SNC80 ((+)-4-[( $\alpha \mathrm{R})-\alpha-((2 \mathrm{~S}, \quad 5 \mathrm{R})-4$-Allyl-2,5-dimethyl-1piperazinyl)-3-methoxybenzyl]- $N, N$-diethylbenzamide (Tocris Cookson Ltd, Ballwin, MO, USA)) and ICI 199441 (Tocris Cookson Ltd, Ballwin, MO, USA) were dissolved in assay buffer containing 20\% ethanol. DAMGO ([D-Ala ${ }^{2}$, $\mathrm{N}$-Me-Phe ${ }^{4}$, Gly ${ }^{5}$-ol] enkephalin) (Sigma Co., St Louis, MO, USA) was dissolved in assay buffer. D-Phe-Cys-TyrD-Trp-Orn-Thr-Pen-Thr-NH ${ }_{2}$ (CTOP; Sigma Chemical Co., MO, USA) and dynorphin A (Peptide Institute Inc., Osaka, Japan) were dissolved in saline for in vivo experiments. Naltrindole hydrochloride (NTI: Tocris Cookson Inc., MO, USA) was dissolved in saline containing $1 \%$ dimethyl sulfoxide. Etizolam (Wako Pure Chemical Industries Ltd, Osaka, Japan) was dissolved in distilled water containing $0.5 \%$ carboxymethyl cellulose sodium salt.

\section{Statistical Analysis}

All data are presented as the mean \pm SEM. The statistical significance of differences between groups was assessed with repeated measures analysis of variance (ANOVA) and one-way ANOVA followed by the Bonferroni-Dunn multiple comparison test or Student's $t$-test. 


\section{RESULTS}

Unilateral intraplantar injection of a CFA solution into the mouse hind paw caused a significant decrease in the latency of paw withdrawal after the thermal stimulus only on the ipsilateral side in mice ( $v s$ saline group, $\mathrm{F}_{1,8}=177.133$, $p<0.001$, Figure 1a). CFA-injected mice also exhibited a significant increase in paw withdrawal in response to the tactile stimulus only on the ipsilateral hind paw in mice ( $v s$ saline group, $\mathrm{F}_{1,8}=154.223, p<0.001$, Figure $1 \mathrm{~b}$ ).

Partial nerve ligation of the sciatic nerve caused a significant decrease in the latency of paw withdrawal after the thermal stimulus only on the ipsilateral side of mice ( $v s$ sham group, $\mathrm{F}_{1,8}=272.452, p<0.001$, Figure 1a). The sciatic
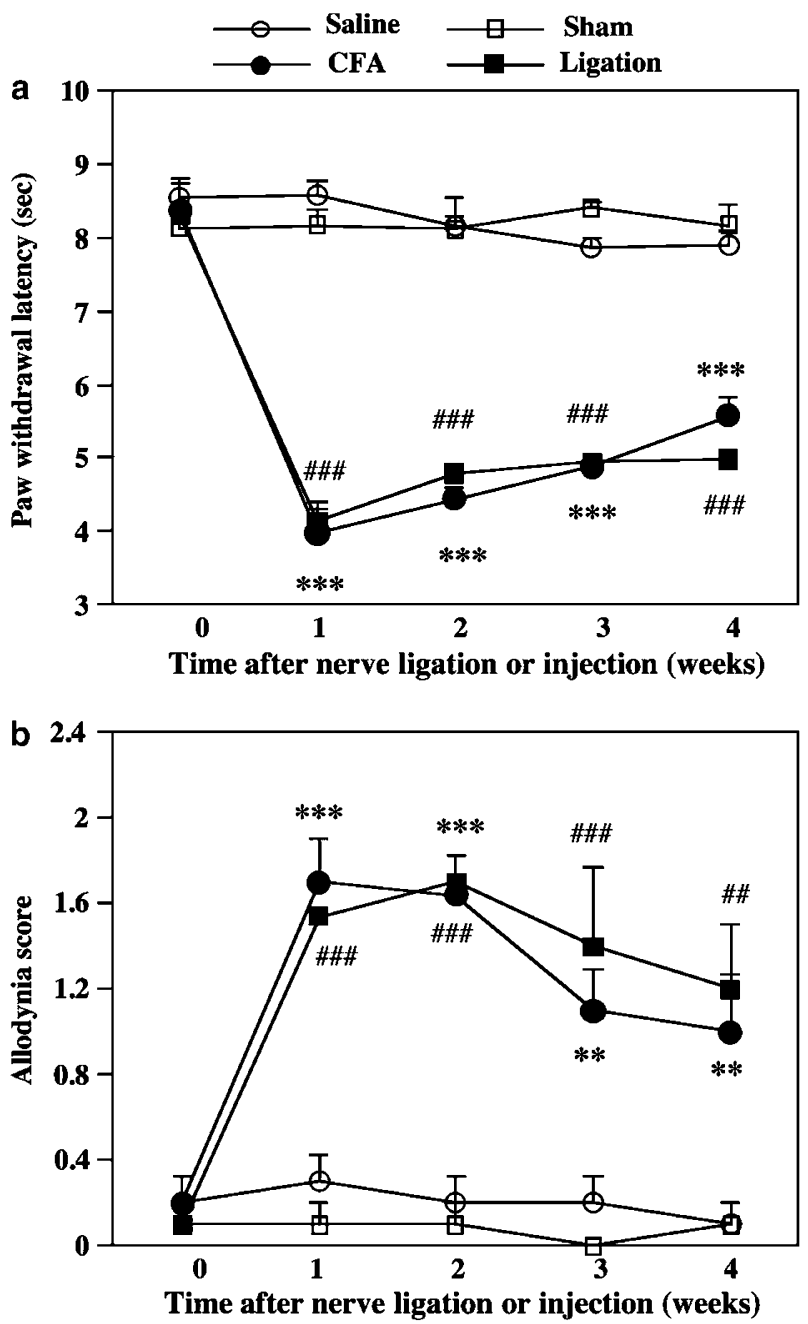

Figure I Changes in the latency of paw withdrawal after thermal and mechanical stimulation induced by the injection of complete Freund's adjuvant (CFA) or sciatic nerve ligation in mice. The data represent the results of (a) paw-withdrawal latencies after the thermal stimulus and (b) paw withdrawal in response to a tactile stimulus on the ipsilateral side at I, 2,3 , and 4 weeks after injection or surgery. There was no difference in the basal response before injection or surgery between saline- and CFA-injected or sham-operated and sciatic nerve-ligated mice. The tactile stimulus was applied using filaments with a bending force of $0.02 \mathrm{~g}$. Each point represents the mean \pm SEM of $6-8$ mice. $* * *<0.01$ and ${ }^{* * *} p<0.00$ I: saline group vs CFA group. ${ }^{\# \#} p<0.01$ and $\#^{\# \#} p<0.001$ : sham group vs ligation group. nerve-ligated mice also exhibited a significant increase in the paw-withdrawal response to the tactile stimulus only on the ipsilateral hind paw in mice ( $v s$ sham group, $\mathrm{F}_{1,8}=50.43, p<0.001$, Figure $1 \mathrm{~b}$ ). Paw-withdrawal latencies and responses on the contralateral side of mice were not changed by injection or surgery (data not shown).

Under these conditions, we investigated whether a chronic pain-like state could induce an anxiogenic effect in mice. In the light-dark test, the time spent in the lit side was similar in both CFA-injected and sciatic nerve-ligated groups at 1,2 , or 3 weeks after injection or surgery. However, CFA-injected and sciatic nerve-ligated mice exhibited a significant decrease in the time spent in the lit side at 4 weeks after CFA injection or surgery ${ }^{* * *} p<0.001$ vs saline 4 weeks group, Figure $2 \mathrm{a})\left({ }^{\# \#} p<0.01\right.$ vs sham 4 weeks group, Figure 2b). In the elevated plus-maze test, the percentage of time spent in the open arms was significantly reduced in CFA-treated mice $\left({ }^{* *} p<0.01\right.$ vs saline 4 weeks group, Figure $3 \mathrm{a})$ and sciatic nerve-ligated mice $\left({ }^{\#} p<0.05\right.$ vs
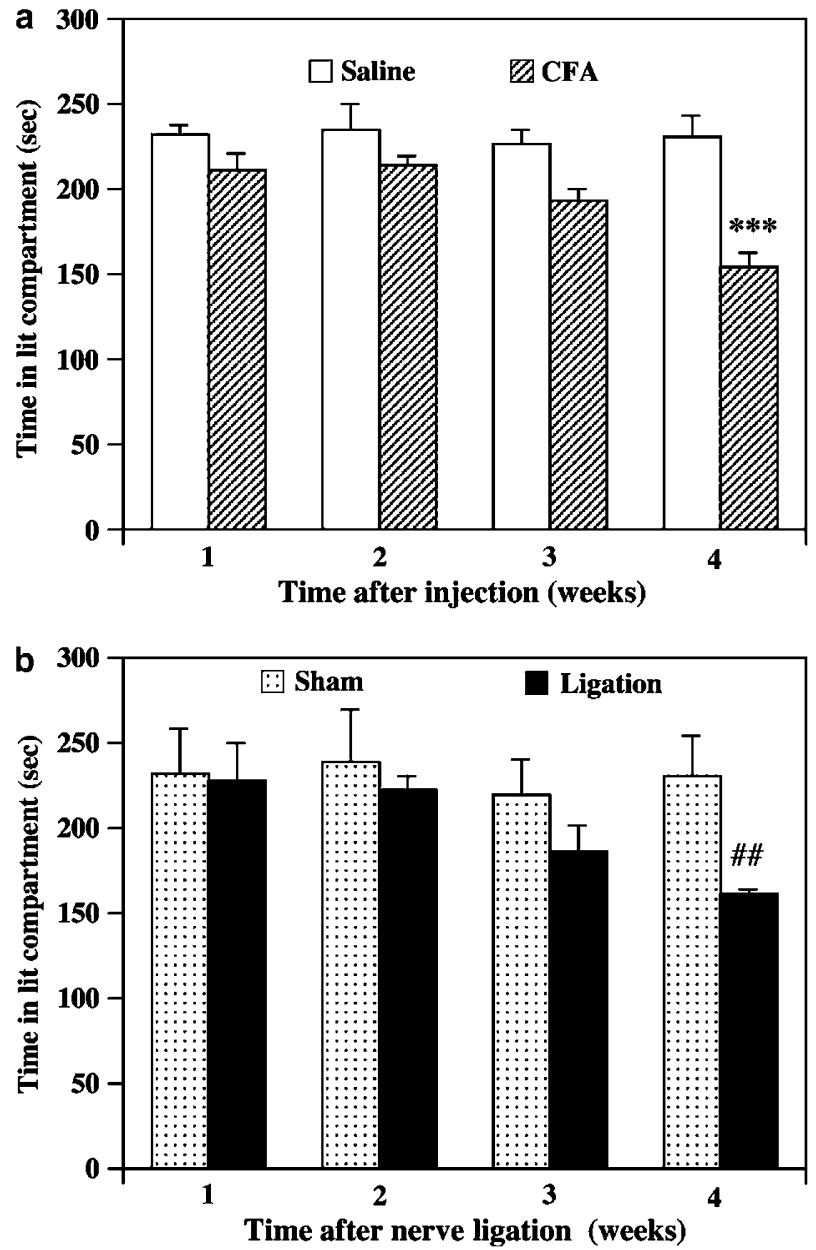

Figure 2 Changes in anxiety behavior in the light-dark test under an inflammatory pain-like state or neuropathic pain-like state in mice. (a) An inflammatory pain-like state caused a significant decrease in the time spent in the lit compartment at 4 weeks after injection. (b) A neuropathic painlike state induced a significant decrease in the time spent in the lit compartment at 4 weeks after surgery. Each column represents the mean \pm SEM of $6-8$ mice. $* * * * * 0.001$ : saline 4 weeks group vs CFA 4 weeks group. ${ }^{\# \#} p<0.0$ I: sham 4 weeks group vs ligation 4 weeks group. 
sham 4 weeks group, Figure $3 \mathrm{~d}$ ) at 4 weeks after injection or surgery. However, the number of entries into the open arms was not significantly reduced in CFA-injected mice (Figure $3 \mathrm{~b}$ ) or sciatic nerve-ligated mice (Figure 3e). The number of entries into closed arms, which was taken as an index of general activity, was not affected by CFA injection (Figure $3 c$ ) or sciatic nerve ligation (Figure $3 f$ ).
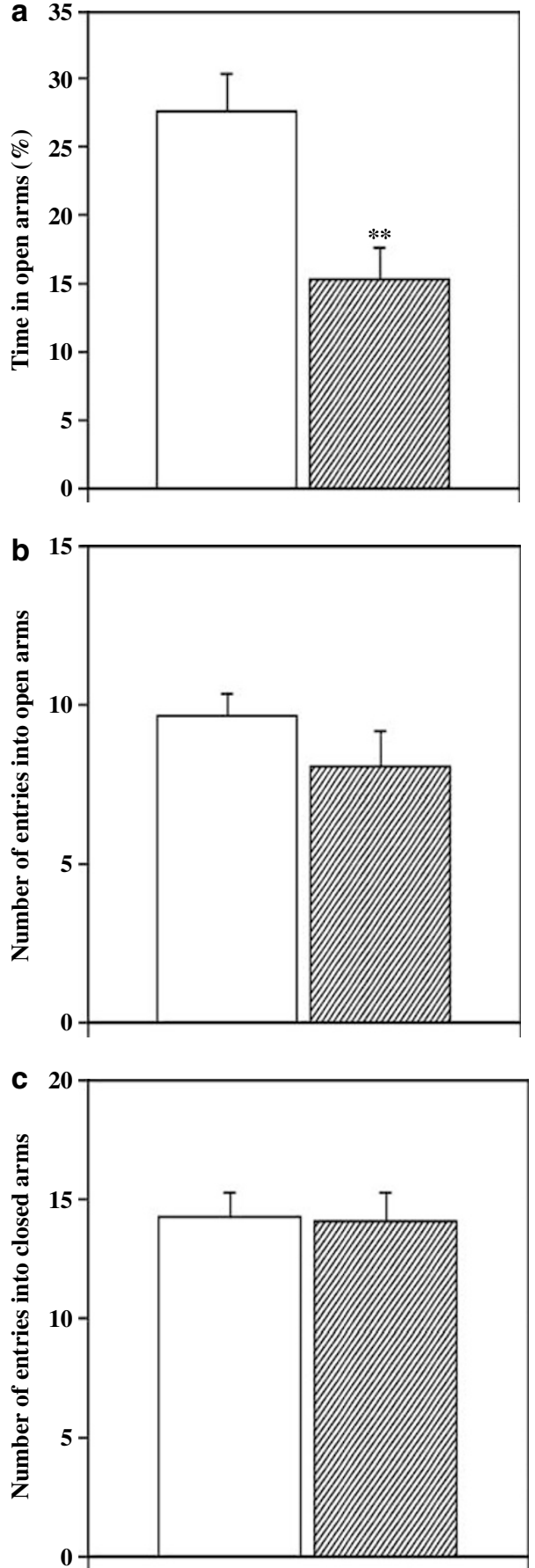

Saline 4 weeks $\mathbb{Z}$ CFA 4 weeks
We next investigated whether a chronic pain-like state could affect G-protein activation through the stimulation of $\mu-, \delta$-, and $\kappa$-opioid receptors in membranes of the amygdala. The ability of the selective $\mu$-opioid receptor agonist DAMGO, the selective $\delta$-opioid receptor agonist SNC80, and the $\kappa$-opioid receptor agonist ICI 199,441 to stimulate G-proteins in membranes of the amygdala
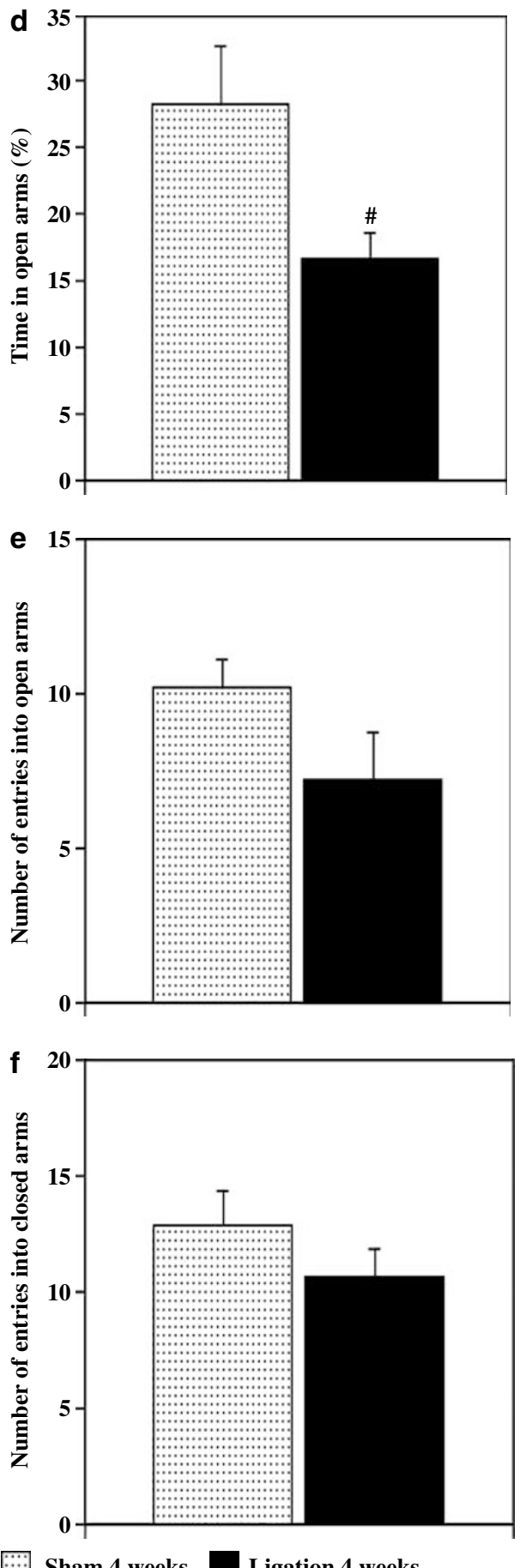

Figure 3 Inflammatory pain- or neuropathic pain-induced anxiogenic effect in the elevated plus-maze test in mice. The percentage of time spent in the open arms was significantly decreased by CFA injection (a) or sciatic nerve ligation (d) at 4 weeks after injection or surgery, respectively. The number of entries into the open arms was similar in both groups ( $b$ and e). There was no change in the number of entries into the closed arms in both groups (c and $f$ ). Each column represents the mean \pm SEM of 6-8 mice. ${ }^{*} * x<0.01$ : saline 4 weeks group vs CFA 4 weeks group. ${ }^{\#}<<0.05$ : sham 4 weeks group vs ligation 4 weeks group. 

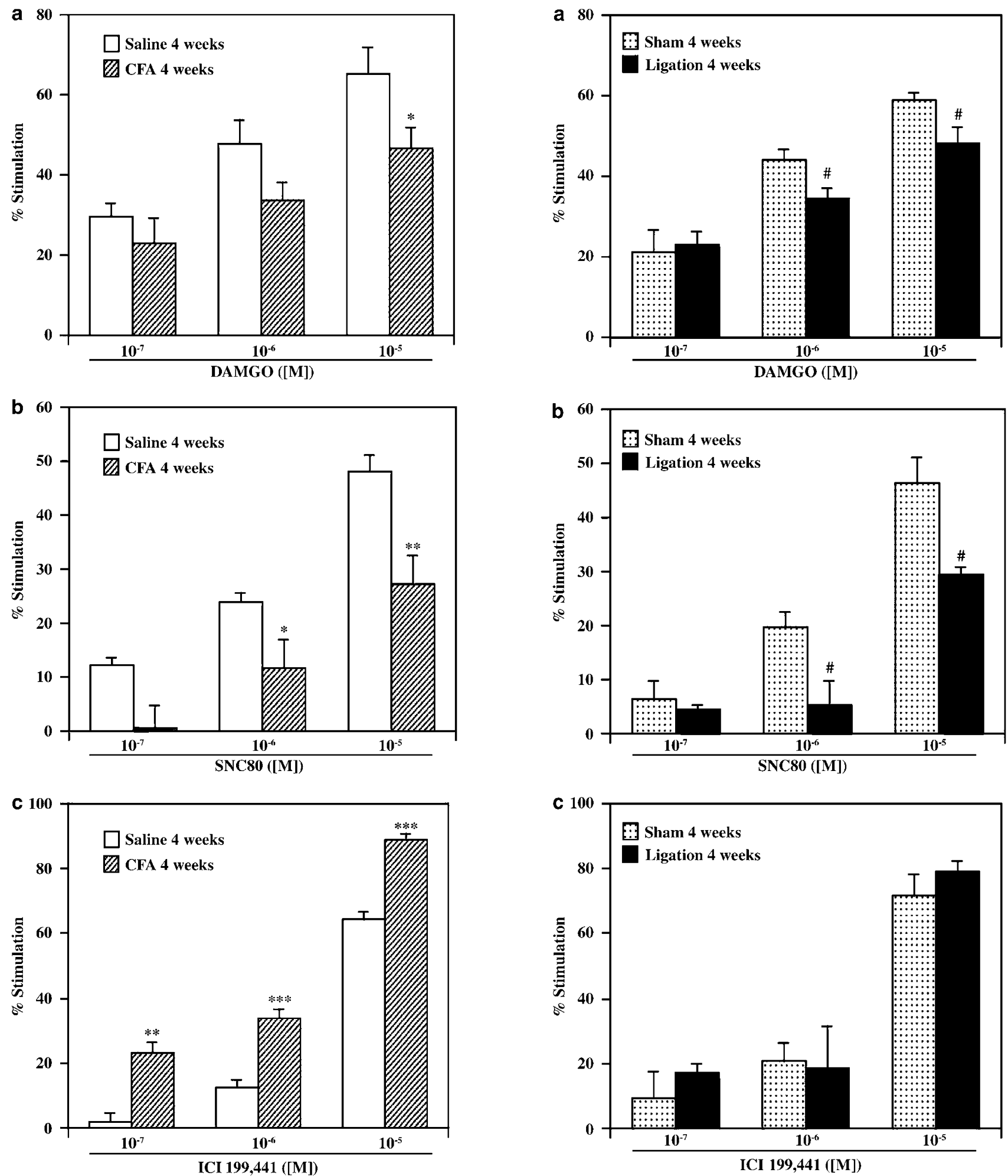

Figure 4 Effects of the selective $\mu$-opioid receptor agonist DAMGO (a), the selective $\delta$-opioid receptor agonist SNC80 (b) and $\kappa$-opioid receptor agonist $|\mathrm{Cl}| 99,44 \mid$ (c) on $\left.{ }^{35} \mathrm{~S}\right] \mathrm{GTP} \gamma \mathrm{S}$ binding to membranes of the amygdala obtained from saline- or CFA-injected mice at 4 weeks after injection. Membranes were incubated with $\left.{ }^{35} \mathrm{~S}\right] \mathrm{GTP} \gamma \mathrm{S}$ (50 pM) and GDP $(30 \mu \mathrm{M})$ with or without each agonist. The data are shown as the percentage of the basal $\left.{ }^{35} \mathrm{~S}\right] \mathrm{GTP} \gamma \mathrm{S}$ binding measured in the presence of GDP and the absence of each agonist. Each column represents the mean with SEM ${ }^{*} p<0.05$, *** $p<0.01$ and ${ }^{* * * *} p<0.00$ I: saline 4 weeks group vs CFA 4 weeks group.

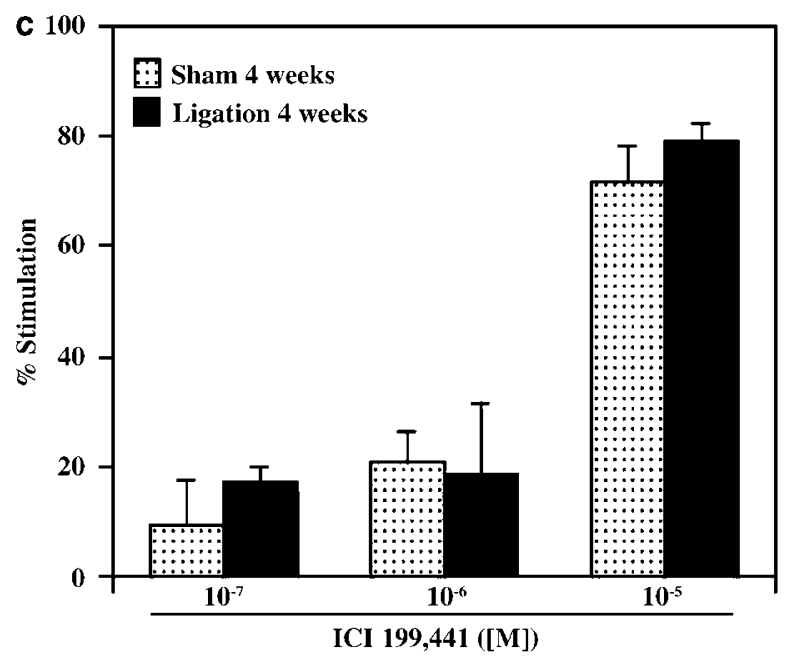

Figure 5 Effects of the selective $\mu$-opioid receptor agonist DAMGO (a), the selective $\delta$-opioid receptor agonist SNC80 (b) and the $\kappa$-opioid receptor agonist ICII9944I (c) on $\left[{ }^{35} \mathrm{~S}\right] \mathrm{GTP} \gamma \mathrm{S}$ binding to membranes of the amygdala obtained from sham-operated or sciatic nerve-ligated mice at 4 weeks after surgery. Membranes were incubated with $\left[{ }^{35} \mathrm{~S}\right] \mathrm{GTP} \gamma \mathrm{S}$ $(50 \mathrm{pM})$ and GDP $(30 \mu \mathrm{M})$ with or without each agonist. The data are shown as the percentage of the basal $\left[{ }^{35} \mathrm{~S}\right] \mathrm{GTP} \gamma \mathrm{S}$ binding measured in the presence of GDP and the absence of each agonist. Each column represents the mean with SEM ${ }^{\#} p<0.05$ : sham 4 weeks group vs ligation 4 weeks group. 
obtained from saline- or CFA-injected mice, sham-operated or sciatic nerve-ligated mice was examined by the binding of $\left[{ }^{35} \mathrm{~S}\right] \mathrm{GTP} \gamma \mathrm{S}$. The stimulatory effect of DAMGO on $\left[{ }^{35} \mathrm{~S}\right] \mathrm{GTP} \gamma \mathrm{S}$ binding to the amygdala membrane was significantly decreased by CFA injection $\left({ }^{*} p<0.05 v s\right.$ saline 4 weeks group, Figure $4 \mathrm{a})$ or sciatic nerve-ligation $\left({ }^{\#} p<0.05\right.$ vs sham 4 weeks group, Figure $5 \mathrm{a}$ ) as compared to saline injection or sham operation. The stimulatory effect of SNC80 on $\left[{ }^{35} \mathrm{~S}\right] \mathrm{GTP} \gamma \mathrm{S}$ binding to membranes of the amygdala was significantly decreased by CFA injection $\left({ }^{\star} p<0.05,{ }^{* *} p<0.01 v s\right.$ saline 4 weeks group, Figure $\left.4 \mathrm{~b}\right)$ or sciatic nerve-ligation ( ${ }^{\#} p<0.05$ vs sham 4 weeks group, Figure $5 \mathrm{~b}$ ) compared to saline injection or sham operation, respectively. The stimulatory effect of ICI 199,441 on $\left[{ }^{35} \mathrm{~S}\right] \mathrm{GTP} \gamma \mathrm{S}$ binding to membranes of the amygdala was significantly increased by CFA injection compared to saline injection ${ }^{* *} p<0.01,{ }^{* *} p<0.001$ vs saline 4 weeks group, Figure $4 c$ ), while sciatic nerve ligation had no effect on ICI 199441 -stimulated $\left[{ }^{35} \mathrm{~S}\right] \mathrm{GTP} \gamma \mathrm{S}$ binding to membranes of the amygdala (Figure 5c). At 1 week after sciatic nerve ligation, there were no significant changes in G-protein activation through $\mu$ - and $\delta$-opioid receptors in membranes of the amygdala (Figure 6).

To elucidate the interactions between opioidergic functions and anxiety, we next investigated whether intracerebroventricular injection of $\mu-, \delta$-opioid receptor antagonist, or dynorphin A could induce an anxiogenic effect using the light-dark test. The time spent in the lit compartment was significantly decreased at $30 \mathrm{~min}$ after intracerebroventricular injection of the selective $\mu$-opioid receptor antagonist CTOP $\left({ }^{\# \#} p<0.01\right.$ vs saline treatment group, Figure 7a) or selective $\delta$-opioid receptor antagonist naltrindole $\left({ }^{* *} p<0.001\right.$ vs vehicle treatment group, Figure $7 \mathrm{~b}$ ). The intracerebroventricular injection of dynorphin A also produced a significant decrease in the time spent in the lit compartment at $30 \mathrm{~min}$ after injection $\left({ }^{\#} p<0.05\right.$ vs saline treatment group, Figure $\left.7 c\right)$.

To further ascertain the direct involvement of opioidergic function in the amygdala in the expression of anxiety, we examined whether microinjection of $\mu$ - or $\delta$-opioid receptor antagonist, or dynorphin A into the amygdala could cause an anxiogenic effect. Using the rat light-dark test, the time
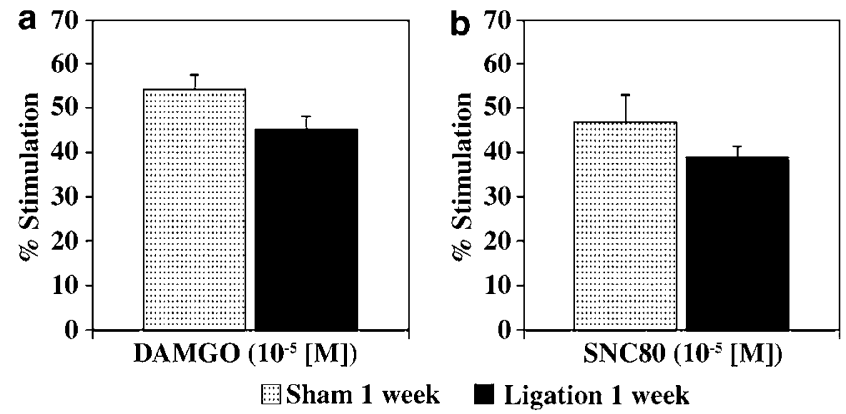

Figure 6 Effect of the selective $\mu$-opioid receptor agonist DAMGO (a) and the $\delta$-opioid receptor agonist SNC80 (b) on $\left.{ }^{35} \mathrm{~S}\right] \mathrm{GTP} \gamma \mathrm{S}$ binding to membranes of the amygdala obtained from sham-operated or sciatic nerve-ligated mice at I week after surgery. Membranes were incubated with $\left[{ }^{35} \mathrm{~S}\right] \mathrm{GTP} \gamma \mathrm{S}(50 \mathrm{pM})$ and GDP $(30 \mu \mathrm{M})$ with or without each agonist. The data are shown as the percentage of that in the presence of GDP and the absence of each agonist. Each column represents the mean with SEM.
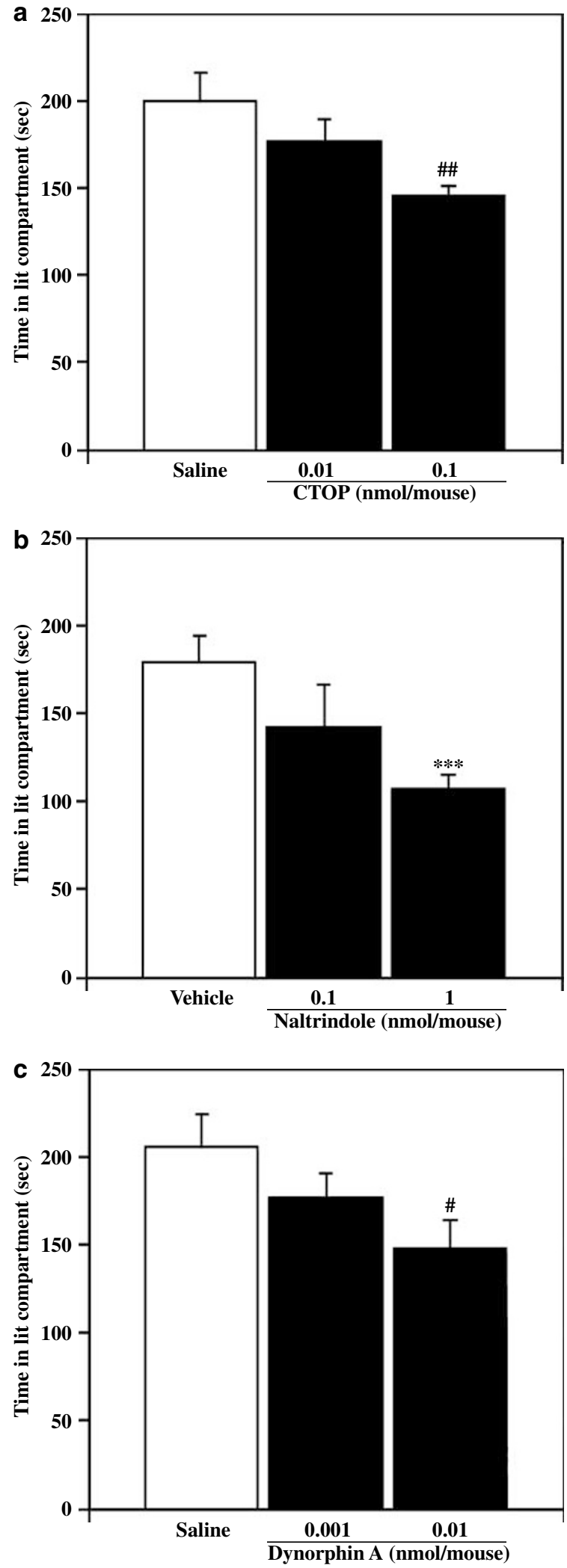

Figure 7 Anxiogenic effects of the selective $\mu$-opioid receptor antagonist CTOP (a), the selective $\delta$-opioid receptor antagonist naltrindole (b) and dynorphin A (c) in mice. The time spent in the lit compartment was significantly decreased at $30 \mathrm{~min}$ after intracerebroventricular injection using the light-dark test. Each column represents the mean \pm SEM of 5-I I mice. ${ }_{*} * * * 0.00$ I: vs vehicle treatment group. ${ }^{\#} p<0.05$ and ${ }^{\# \#} p<0.01$ I: vs saline treatment group. 
spent in the lit compartment was significantly decreased at 10 min after the microinjection of either CTOP $\left({ }^{\#} p<0.05\right.$ vs saline treatment group, Figure $8 \mathrm{a}$ ) or naltrindole into the
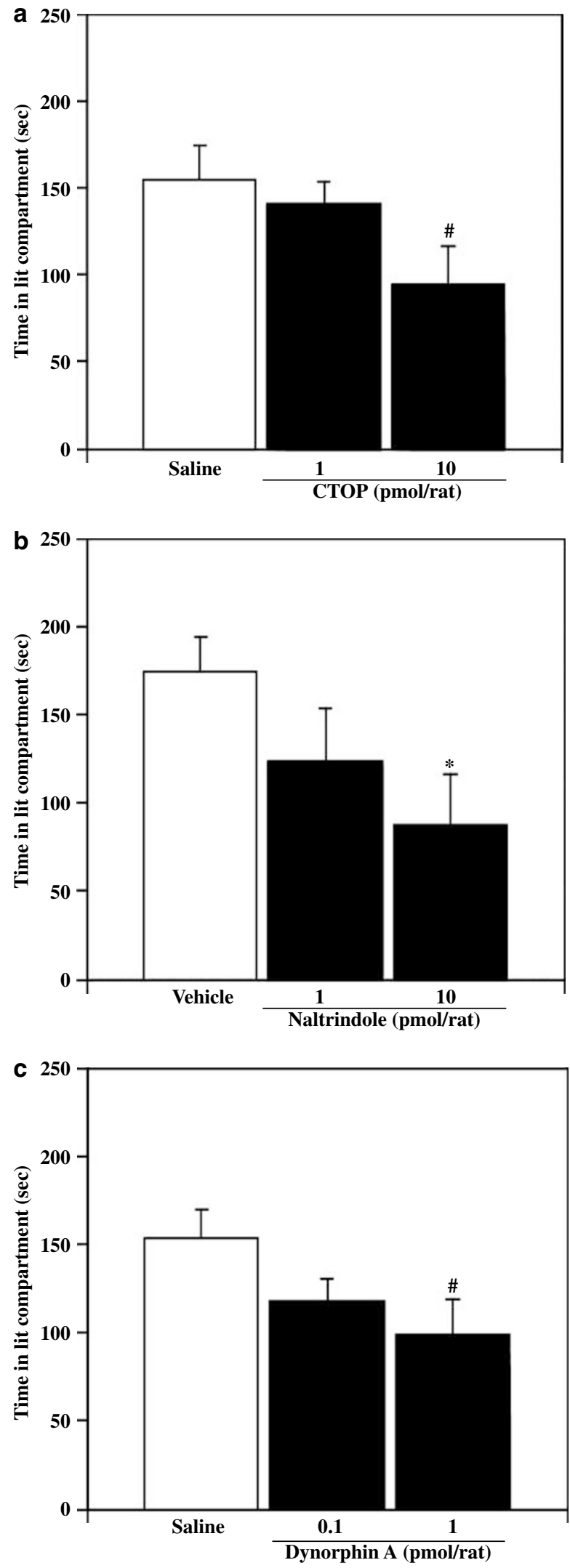

amygdala $\left({ }^{*} p<0.05 v s\right.$ vehicle treatment group, Figure $\left.8 \mathrm{~b}\right)$. The microinjection of dynorphin $\mathrm{A}$ into the rat amygdala also produced a significant decrease in the time spent in the lit compartment at $10 \mathrm{~min}$ after injection $\left({ }^{\#} p<0.05 v s\right.$ saline treatment group, Figure 8c).

At 8 weeks after surgery, thermal hyperalgesia induced by sciatic nerve ligation was reversed (Figure 9a). In the light-dark test, the decrease in the time spent in the lit compartment was also reversed at 8 weeks after surgery (Figure 9b). Eight weeks after sciatic nerve ligation, there were no significant changes in the G-protein activation through $\mu$ - and $\delta$-opioid receptors in membranes of the amygdala (Figure 10).

Finally, we investigated whether the anxiolytic agent could affect the pain perception. To ascertain the effect of s.c. injection of etizolam on paw withdrawal latencies at the ipsilateral and the contralateral sides in sham-operated or nerve-ligated mice, each paw was measured just before and $30 \mathrm{~min}$ after etizolam injection. At the beginning of this experiment, we confirmed that acute treatment with etizolam $(1 \mathrm{mg} / \mathrm{kg}$, s.c.) produced a significant increase in a percent of the open arm entries and the percent of time spent in the open arms of the maze in the plus-maze test (Figure 11a-c) and time spent in the lit zone in the lightdark test $\left({ }^{*} p<0.05 v s\right.$ vehicle treatment group, Figure 11d), indicating the possible expression of an anxiolytic-like effect induced by etizolam at $1 \mathrm{mg} / \mathrm{kg}$ through the stimulation of $\mathrm{GABA}_{\mathrm{A}}$ receptor. Under these conditions, the decreased thermal threshold on the ipsilateral side in nerve-ligated mice was not affected by a single s.c. injection of etizolam treatment at $1 \mathrm{mg} / \mathrm{kg}$ (Figure 11e). To further investigate the effect of chronic etizolam treatment on the sensitivity to the thermal stimulation, mice were treated repeatedly with etizolam $(1 \mathrm{mg} / \mathrm{kg}$, s.c.) once a day for 3 weeks (from day 7 to day 28) after nerve ligation. As a
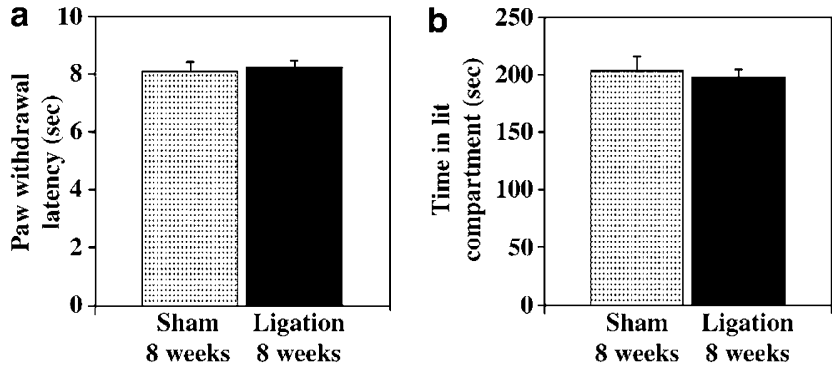

Figure 9 Recovery from the sciatic nerve ligation-induced-anxiogenic effect at 8 weeks after surgery. (a) The latency of paw withdrawal after exposure to a thermal stimulus was not changed at 8 weeks after surgery. (b) The time spent in the lit compartment was no change at 8 weeks after the surgery using the light-dark test. Each column represents the mean \pm SEM of eight mice.

Figure 8 Role of the rat amygdala in the expression of anxiogenic effects induced by the selective $\mu$-opioid receptor antagonist CTOP (a), the selective $\delta$-opioid receptor antagonist naltrindole (b) and dynorphin A (c). The time spent in the lit compartment was a significant decrease at 10 min after each microinjection using the light-dark test. Each column represents the mean \pm SEM of $5-11$ rat. $* p<0.05$ : vs vehicle treatment group. $\# p<0.05$ : vs saline treatment group. 

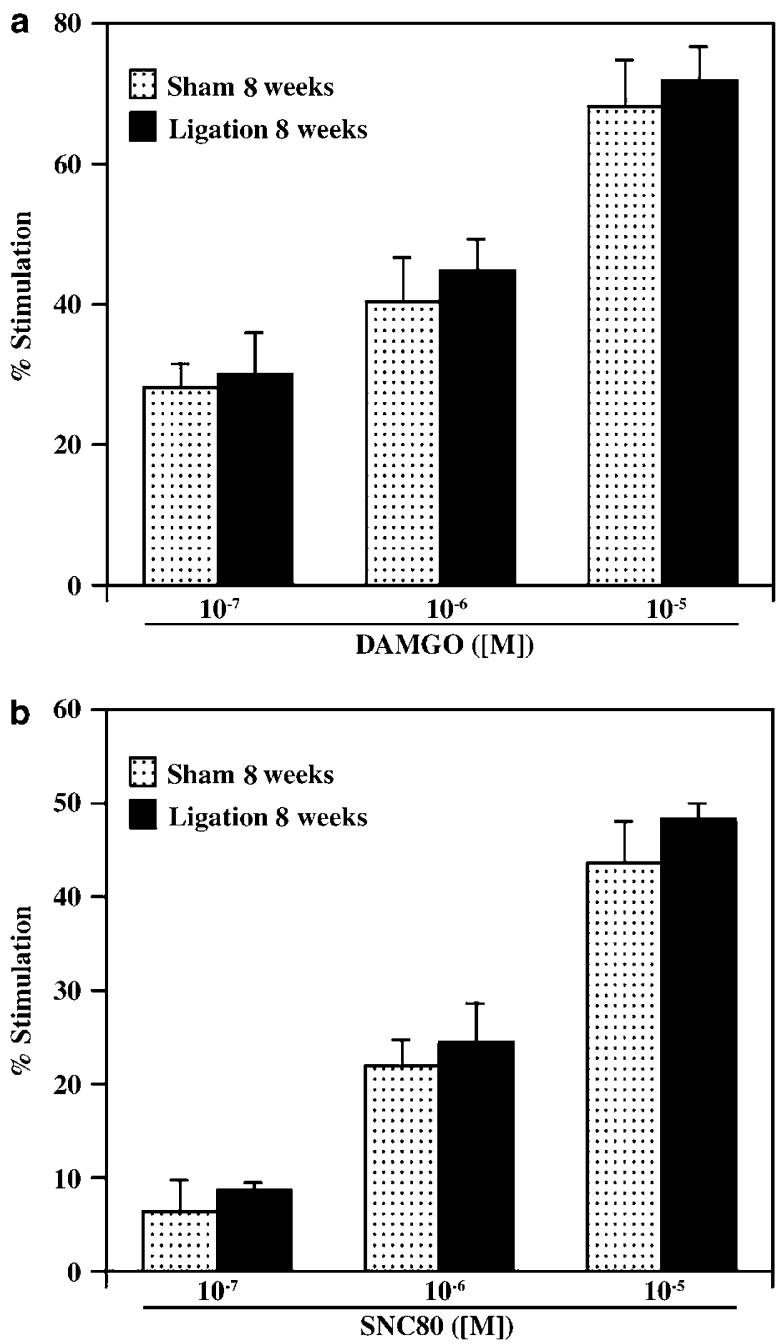

Figure 10 Effects of the selective $\mu$-opioid receptor agonist DAMGO (a) and the $\delta$-opioid receptor agonist SNC80 (b) on $\left[{ }^{35} \mathrm{~S}\right] \mathrm{GTP} \gamma \mathrm{S}$ binding to membranes of the amygdala obtained from sham-operated or sciatic nerve-ligated mice at 8 weeks after surgery. Membranes were incubated with $\left[{ }^{35} \mathrm{~S}\right] \mathrm{GTP} \gamma \mathrm{S}(50 \mathrm{pM})$ and GDP $(30 \mu \mathrm{M})$ with or without each agonist. The data are shown as the percentage of the results in the presence of GDP and the absence of each agonist. Each column represents the mean with SEM.

result, there were no changes in the decreased thermal threshold between on the ipsilateral sides in vehicle- and etizolam-treated mice after nerve ligation (Figure 11j), whereas the increased anxiety-like behavior after nerve ligation was abolished by chronic treatment with etizolam (Figure 11f-i).

\section{DISCUSSION}

The relationship between depression and pain is well known. Some functional changes in the emotionality-related brain regions must occur in association with chronic pain. However, little is known about the molecular mechanism that underlies pain-induced anxiety. The present study was undertaken to investigate whether chronic pain could induce an anxiogenic effect in mice. Thermal hyperalgesia and tactile allodynia induced by either CFA injection or sciatic nerve ligation lasted for at least 4 weeks after injection or surgery. Under these conditions, we found that either an inflammatory or neuropathic pain-like state led to an anxiogenic effect at 4 weeks after CFA injection or surgery, respectively, in mice. Furthermore, thermal hyperalgesia induced by sciatic nerve ligation was reversed at 8 weeks after surgery. In the light-dark test, the time spent in the lit compartment was not changed at 8 weeks after surgery. These findings suggest that pain and anxiety are closely connected.

Many studies have shown that the amygdala plays a key role in fear and anxiety (Davis et al, 1994; Moller et al, 1997). The distributions of $\mu-, \delta$-, and $\kappa$-opioid receptor mRNAs overlap in many brain regions including the amygdala (Mansour et al, 1995). The amygdala also has high levels of endogenous opioid peptides (Mansour et al, 1995). Therefore, we next investigated whether chronic pain could change opioidergic function in the amygdala. In the present study, the stimulatory effect of the selective $\mu$ opioid receptor agonist DAMGO or the selective $\delta$-opioid receptor agonist SNC80 on $\left[{ }^{35} \mathrm{~S}\right] \mathrm{GTP} \gamma \mathrm{S}$ binding to the amygdala membranes was significantly decreased by either CFA injection or sciatic nerve ligation as compared to saline injection or sham operation. In contrast, $\kappa$-opioid receptor agonist ICI 199,441-induced G-protein activation in the amygdala was significantly increased by CFA injection, but not sciatic nerve ligation. This phenomenon is consistent with our previous findings that inflammatory pain, but not nerve injury, causes a marked activation of endogenous $\kappa$ opioidergic system (Ozaki et al, 2002; Narita et al, 2005). At 1 week after the sciatic nerve ligation, thermal hyperalgesia and allodynia, but not an anxiogenic effect, were observed with nerve ligation. Under these conditions, there were no significant changes in G-protein activation through $\mu$ - and $\delta$-opioid receptors in membranes of the amygdala. These findings raise the possibility that chronic pain-induced changes in opioidergic function in the amygdala may lead to the anxiogenic effect.

In the present study, we also found that intracerebroventricular administration and microinjection of either $\mu$-opioid receptor antagonists, a $\delta$-opioid receptor antagonist, or dynorphin A into the amygdala caused a significant anxiogenic effect in mice. Recently, it has been reported that $\delta$-opioid receptor knockout mice exhibit more anxiety behavior (Filliol et al, 2000). In addition, intracerebroventricular injection of dynorphin A increases forced swimming-induced immobility in mice (Katoh et al, 1990). These data support the idea that the dysfunction of $\mu$-, $\delta$-opioid receptors (and the possible enhancement of $\kappa$-opioid receptor function) in the amygdala may, at least in part, play a role in the mood altering effect of chronic pain.

As previously reported in healthy human subjects, sustained pain induces a reduction of $\mu$-opioid receptor availability in the amygdala as measured by positron emission tomography (Zubieta et al, 2001). Based on previous work in experimental animals, it was hypothesized that a painful condition could be associated with an increased release of endogenous opioids in the amygdala (Manning, 1998). These data support the hypothesis that sustained pain induces a regionally selective release of endogenous opioids interacting with $\mu$-opioid receptors in 
a

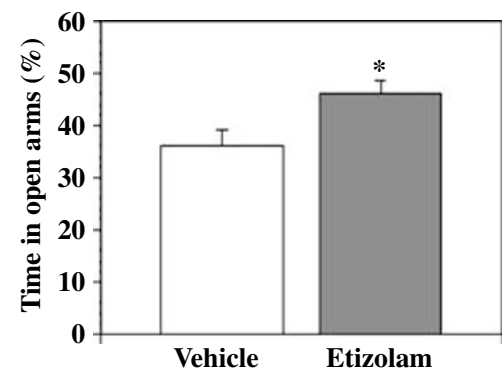

d

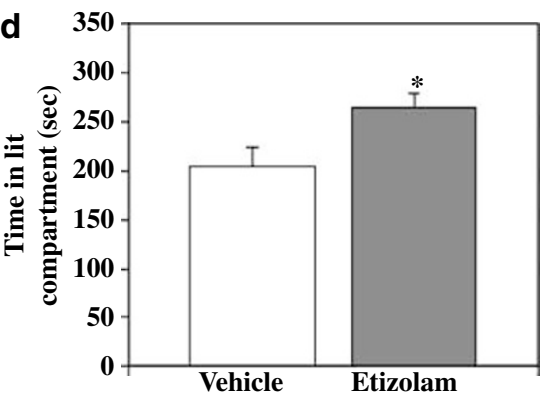

f
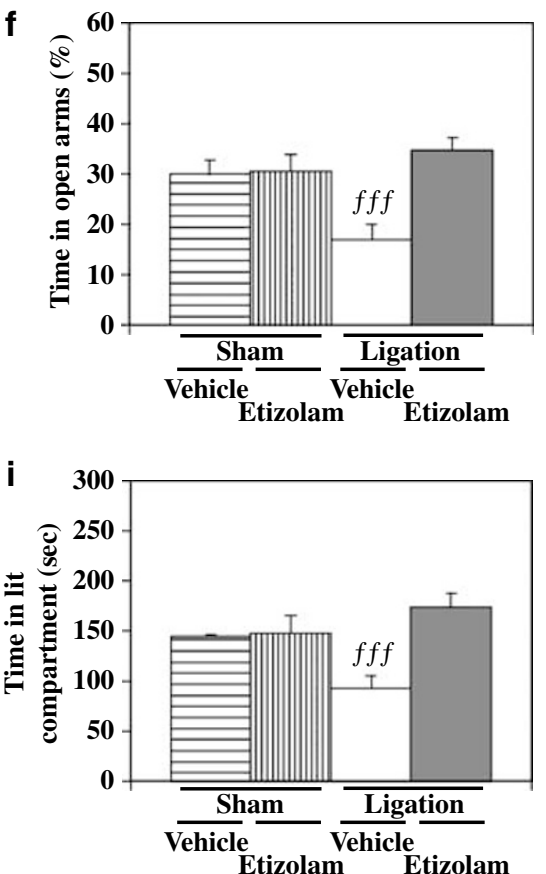
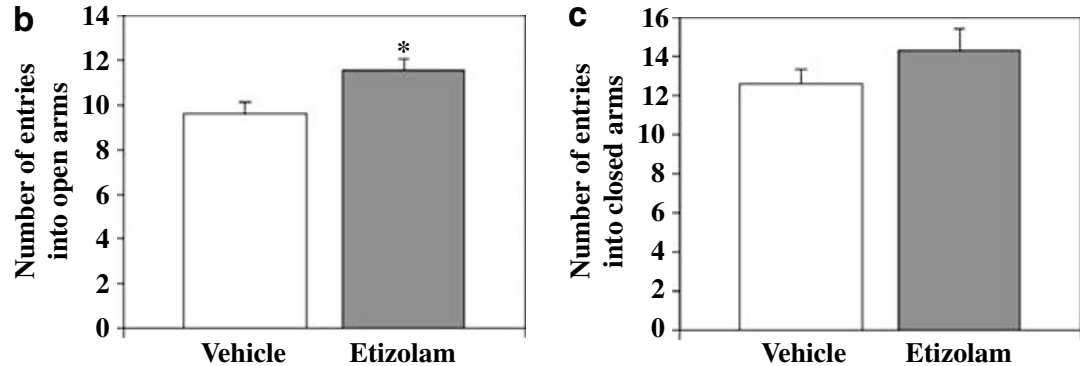

e
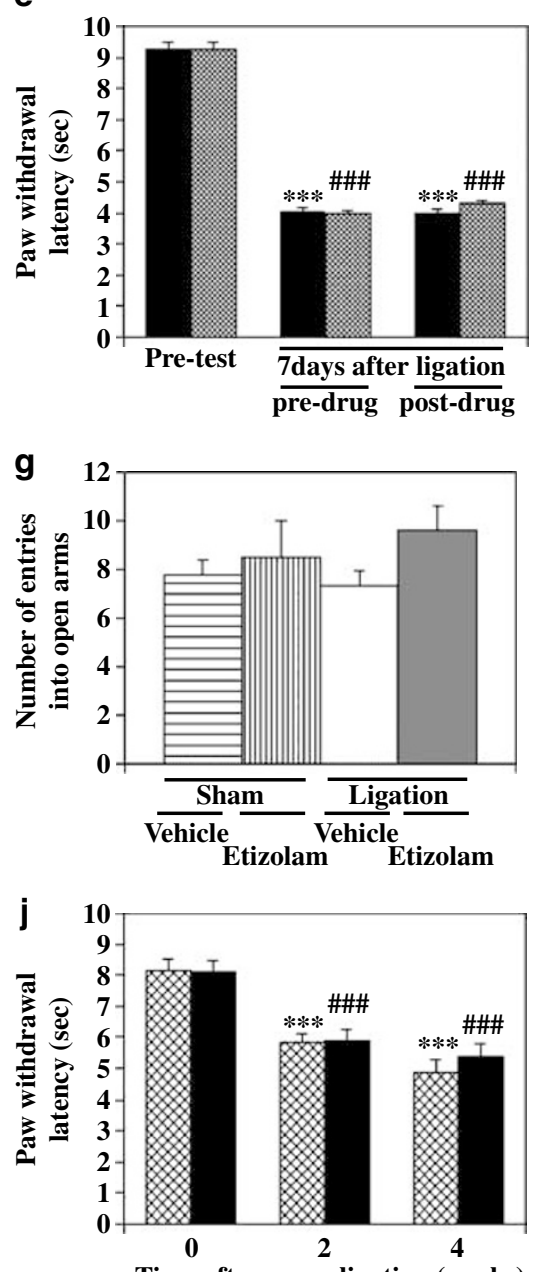

Time after nerve ligation (weeks)
Vehicle

Etizolam

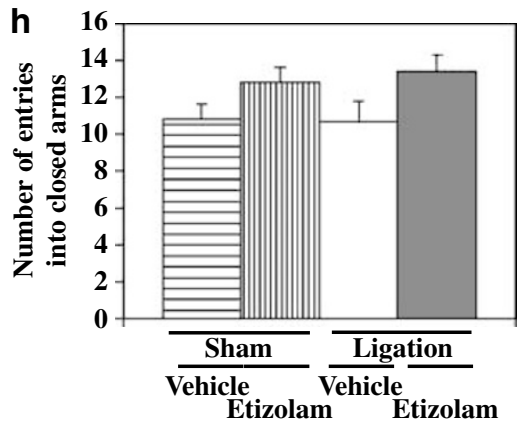

Etizolam

\section{Vehicle \\ Etizolam}

Figure I I Effects of the selective benzodiazepine receptor agonist etizolam on anxiogenic ( $\mathrm{a}-\mathrm{d}$ and $\mathrm{f}-\mathrm{i}$ ) and hyperalgesic (e and $\mathrm{j}$ ) effects induced by sciatic nerve ligation. Acute treatment with etizolam ( $\mathrm{l} \mathrm{mg/kg}$, s.c.) produced a significant increase in the percentage of the time spent in open arms (a) and the number of entries into open arms (b) in the elevated plus-maze test ( $p<<0.05$ : vehicle vs etizolam). (c) There was no difference in the number of entries into closed arms between the vehicle- and etizolam-treated mice. (d) Acute treatment wiith etizolam (I mg/kg, s.c.) caused a significant increase in time spent in the lit compartment using the light-dark test (* $<0.05$ : vehicle vs etizolam). (e) At 7 days after nerve ligation, the thermal threshold was significantly decreased ( $* * * * \# \#$, \# 0.00 I: pretest vs prevehicle and pre-etizolam, respectively). After confirming the predrug threshold at 7 days after nerve ligation, mice were treated with a single injection of vehicle or etizolam ( $\mathrm{mg} / \mathrm{kg}$, s.c.) and the thermal threshold was measured 30 min after the injection (postdrug). The decreased thermal threshold on the ipsilateral side in nerve-ligated mice was not affected by a single injection of etizolam (I mg/kg, s.c., no significance: predrug vs postdrug). ( $\mathrm{f}-\mathrm{i})$ Neuropathic pain induced the anxiogenic effect in the elevated plus-maze ( $\mathrm{f}-\mathrm{h}$ ) and the light-dark (i) tests. Groups of mice were operated with or without sciatic nerve ligation and each groups was divided into two groups: chronic vehicle treatment and chronic etizolam treatment. Mice were repeatedly injected with vehicle or etizolam ( I mg/kg, s.c.) once a day for 3 weeks (from day 7 to day 28) after nerve ligation. The assay was performed one day after last injection. The decreased percentage of time spent in the open arms was completely recovered by repeatedly s.c. treatment with etizolam ( $f$ ( $(f f p<0.00$ I: vs sham-vehicle). There was no change in the number of entries into the open ( $g$ ) and closed (h) arms in each group. The decreased time spent in the lit compartment was significantly recovered by repeatedly s.c. treatment with etizolam (i) (fff $p<0.001$ : vs sham-vehicle). (j) At 2 and 4 weeks after nerve ligation, the thermal threshold was significantly decreased (***, \#\#\# $p<0.00$ I: vehicle 0 week vs vehicle 2 and 4 weeks, \#\#\# $p<0.00$ I: etizolam 0 week vs etizolam 2 and 4 weeks, respectively). Under these conditions, there was no difference in the decreased thermal threshold on the ipsilateral sides between vehicle- and etizolam-treated mice following nerve ligation. Each column represents the mean \pm SEM of 6-8 mice. 
the amygdala, resulting in the internalization and recycling of $\mu$-opioid receptors.

We previously reported that morphine failed to induce rewarding effects under a neuropathic pain-like state in the rat and mouse (Ozaki et al, 2002, 2003). Furthermore, this pain-like state is associated with a reduction in $\mu$-opioid receptor function in the ventral tegmental area (Ozaki et al, 2002, 2003). We also found that an inflammatory pain-like state could cause a sustained activation of the $\kappa$-opioidergic system in the nucleus accumbens, leading to suppression of the morphine-induced rewarding effect in rats (Suzuki et al, 1999; Narita et al, 2005). Taken together, these findings suggest that a state of pain may cause physiological changes in opioid transmission at supraspinal levels. Furthermore, there may be differences in the mechanisms between the neuropathic and inflammatory pain-like states. Although further study is needed, this phenomenon could explain why the $\kappa$-opioid receptor function in the amygdala was changed by inflammation, but not by nerve injury.

Another key finding was that acute and chronic treatments with a selective benzodiazepine receptor agonist etizolam $(1 \mathrm{mg} / \mathrm{kg}$, s.c.), which clearly showed a significant anxiolytic effect in normal mice and a complete suppression of the expression of anxiety under a neuropathic painlike state, failed to improve the increased pain-sensitivity after nerve injury. In our preliminary study, we found that chronic psychological stress produced a significant decrease in thermal thresholds, whereas subchronic treatment with a selective benzodiazepine receptor inverse agonist FG7142 failed to alter the increased pain-sensitivity under a chronic pain-like state (data not shown). Thus, we propose that, although chronic pain and negative emotions including anxiety and depression are concomitant constructs because of similar biological foundations and the negative emotions can be increased by chronic pain, chronic pain is not always suppressed by the treatment with anxiolytic drugs. In contrast, we cannot exclude the possibility that chronic pain-induced negative emotions cause some pain and/or lead to an increase of painsensitivity (Figure 12).

In conclusion, the present data constitute the first evidence that chronic pain has an anxiogenic effect in mice, which may be associated with changes in opioidergic function in the amygdala.

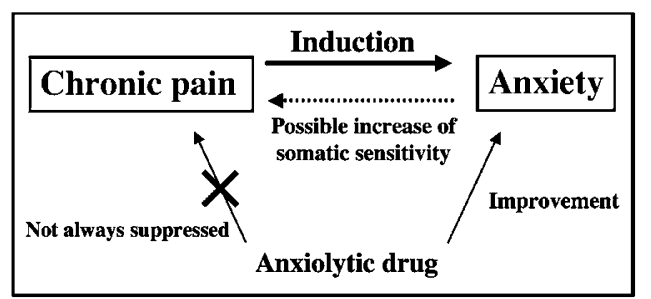

Figure 12 Conceptual frameworks for the presumed interaction between chronic pain and anxiety. Negative emotions such as anxiety can result from the experience of chronic pain. When the anxiolytic drug is treated under a chronic pain-like state, the anxiety can be improved by the drug. However, it is likely that chronic pain is not always suppressed by the anxiolytic drug. In contrast, anxiety could increase somatic sensitivity.

\section{ACKNOWLEDGEMENTS}

This work was supported by a Research Grant from the Ministry of Education, Culture, Sports, Science and Technology of Japan. We thank Ms Saori Kitaya for her technical assistance.

\section{REFERENCES}

Bilkei-Gorzo A, Gyertyan I, Levay G (1998). mCPP-induced anxiety in the light-dark box in rats-a new method for screening anxiolytic activity. Psychopharmacology 136: 291298.

Broom DC, Jutkiewicz EM, Folk JE, Traynor JR, Rice KC, Woods $\mathrm{JH}$ (2002). Nonpeptidic $\delta$-opioid receptor agonists reduce immobility in the forced swim assay in rats. Neuropsychopharmacology 26: 744-755.

Cahill CM, Morinville A, Lee MC, Vincent JP, Collier B, Beaudet A (2001). Prolonged morphine treatment targets delta opioid receptors to neuronal plasma membranes and enhances delta-mediated antinociception. J Neurosci 21: 7598-7607.

Chen Y, Mestek A, Liu J, Hurley JA, Yu L (1993). Molecular cloning and functional expression of a mu-opioid receptor from rat brain. Mol Pharmacol 44: 8-12.

Davis M, Rainnie D, Cassell M (1994). Neurotransmission in the rat amygdala related to fear and anxiety. Trends Neurosci 17: 208-214.

Dawson GR, Tricklebank MD (1995). Use of the elevated plus maze in the search for novel anxiolytic agents. Trends Pharmacol Sci 16: $33-36$

degli Uberti EC, Petraglia F, Bondanelli M, Guo AL, Valentini A, Salvadori S et al (1995). Involvement of mu-opioid receptors in the modulation of pituitary-adrenal axis in normal and stressed rats. J Endocrinol Invest 18: 1-7.

Dworkin RH, Gitlin MJ (1991). Clinical aspects of depression in chronic pain patients. Clin J Pain 7: 79-94.

Evans CJ, Keith Jr DE, Morrison H, Magendzo K, Edwards RH (1992). Cloning of a delta opioid receptor by functional expression. Science 258: 1952-1955.

Filliol D, Ghozland S, Chluba J, Martin M, Matthes HW, Simonin F et al (2000). Mice deficient for $\delta$ - and $\mu$-opioid receptors exhibit opposing alterations of emotional responses. Nat Genet 25: 195-200.

Fukuda K, Kato S, Mori K, Nishi M, Takeshima H (1993). Primary structures and expression from cDNAs of rat opioid receptor delta- and mu-subtypes. FEBS Lett 327: 311-314.

Gallagher RM, Moore P, Chernoff I (1995). The reliability of depression diagnosis in chronic low back pain. Gen Hosp Psychiatry 17: 399-413.

Haley MJ, McCormick WG (1957). Pharmacological effects produced by intracerebral injections of drugs in the conscious mouse. Br J Pharmacol 12: 12-15.

Katoh A, Nabeshima T, Kameyama T (1990). Behavioral changes induced by stressful situations: effects of enkephalins, dynorphin, and their interactions. J Pharmacol Exp Ther 253: 600-607.

Kieffer BL, Befort K, Gaveriaux-Ruff C, Hirth CG (1992). The deltaopioid receptor: isolation of a cDNA by expression cloning and pharmacological characterization. Proc Natl Acad Sci USA 89: 12048-12052.

Kiritsy-Roy JA, Appel NM, Bobbitt FG, Van Loon GR (1986). Effects of mu-opioid receptor stimulation in the hypothalamic paraventricular nucleus on basal and stress-induced catecholamine secretion and cardiovascular responses. J Pharmacol Exp Ther 239: 814-822.

Manning BH (1998). A lateralized deficit in morphine antinociception after unilateral inactivation of the central amygdala. J Neurosci 18: 9453-9470. 
Mansour A, Fox CA, Akil H, Watson SJ (1995). Opioid-receptor mRNA expression in the rat CNS: anatomical and functional implications. Trends Neurosci 18: 22-29.

Mansour A, Khachaturian H, Lewis ME, Akil H, Watson SJ (1988). Anatomy of CNS opioid receptors. Trends Neurosci 11: 308-314.

Meng F, Xie GX, Thompson RC, Mansour A, Goldstein A, Watson SJ et al (1993). Cloning and pharmacological characterization of a rat kappa opioid receptor. Proc Natl Acad Sci USA 90: 99549958.

Moller C, Wiklund L, Sommer W, Thorsell A, Heilig M (1997). Decreased experimental anxiety and voluntary ethanol consumption in rats following central but not basolateral amygdala lesions. Brain Res 760: 94-101.

Narita M, Kishimoto Y, Ise Y, Yajima Y, Misawa K, Suzuki T (2005). Direct evidence for the involvement of the mesolimbic kappa-opioid system in the morphine-induced rewarding effect under an inflammatory pain-like state. Neuropsychopharmacology 30: 111-118.

Narita M, Yajima Y, Aoki T, Ozaki S, Narita M, Mizoguchi H et al (2000). Up-regulation of the TrkB receptor in mice injured by the partial ligation of the sciatic nerve. Eur J Pharmacol 401: 187-190.

Ohsawa M, Narita M, Mizoguchi H, Suzuki T, Tseng LF (2000). Involvement of spinal protein kinase $\mathrm{C}$ in thermal hyperalgesia evoked by partial sciatic nerve ligation, but not by inflammation in the mouse. Eur J Pharmacol 403: 81-85.

Ozaki S, Narita M, Narita M, Iino M, Miyoshi K, Suzuki T (2003). Suppression of the morphine-induced rewarding effect and Gprotein activation in the lower midbrain following nerve injury in the mouse: involvement of G-protein-coupled receptor kinase 2. Neuroscience 116: 89-97.

Ozaki S, Narita M, Narita M, Iino M, Sugita J, Matsumura Y et al (2002). Suppression of the morphine-induced rewarding effect in the rat with neuropathic pain: implication of the reduction in $\mu$-opioid receptor functions in the ventral tegmental area. J Neurochem 82: 1192-1198.

Pasternak GW (1988). The Opiate Receptors. The Human Press: Clifton, NJ.

Paxinos G, Watson G (1998). The Rat Brain in Stereotaxic Coordinates, 4th edn. Academic Press: New York.

Pfeiffer A, Brantl V, Herz A, Emrich HM (1986). Psychotomimesis mediated by kappa opiate receptors. Science 233: 774-776.

Schramm NL, McDonald MP, Limbird LE (2001). The alpha(2a)-adrenergic receptor plays a protective role in mouse behavioral models of depression and anxiety. J Neurosci 21: 4875-4882.

Suzuki T, Kishimoto Y, Misawa M, Nagase H, Takeda F (1999). Role of the kappa-opioid system in the attenuation of the morphine-induced place preference under chronic pain. Life Sci 64: PL1-PL7.

Von Korff M, Simon G (1996). The relationship between pain and depression. Br J Psychiatry Suppl 30: 101-108.

Wang JB, Imai Y, Eppler CM, Gregor P, Spivak CE, Uhl GR (1993). $\mathrm{Mu}$ opiate receptor: cDNA cloning and expression. Proc Natl Acad Sci USA 60: 10230-10234.

Yajima Y, Narita M, Usui A, Kaneko C, Miyatake M, Narita M et al (2005). Direct evidence for the involvement of brain-derived neurotrophic factor in the development of neuropathic pain-like state in mice. J Neurochem 93: 584-594.

Yasuda K, Raynor K, Kong H, Breder CD, Takeda J, Reisine T et al (1993). Cloning and functional comparison of kappa and delta opioid receptors from mouse brain. Proc Natl Acad Sci USA 90: 6736-6740.

Zubieta JK, Smith YR, Bueller JA, Xu Y, Kilbourn MR, Jewett DM et al (2001). Regional mu opioid receptor regulation of sensory and affective dimensions of pain. Science 293: 311-315. 